\title{
The Rat Model in Microsurgery Education: Classical Exercises and New Horizons
}

\author{
Sandra Shurey ${ }^{1}$, Yelena Akelina ${ }^{2}$, Josette Legagneux ${ }^{3}$, Gerardo Malzone ${ }^{4}$, Lucian Jiga ${ }^{5}$, \\ Ali Mahmoud Ghanem ${ }^{6}$ \\ ${ }^{1}$ Northwick Park Institute for Biomedical Research, Imperial College, London, UK; ${ }^{2}$ Microsurgery Research and Training Laboratory, \\ Columbia University, New York, USA; ${ }^{3}$ Microsurgery Training and Research Lab, Paris School of Surgery, Paris, France; Department of \\ Plastic Surgery Sapienza University, Rome, Italy; ${ }^{5}$ Pius Branzeu Centre for Laparoscopic Surgery and Microsurgery, Timisoara, Romania; \\ ${ }^{6}$ Microvascular Anastomosis Simulation Hub, Barts and the London School of Medicine and Dentistry, London, UK
}

Microsurgery is a precise surgical skill that requires an extensive training period and the supervision of expert instructors. The classical training schemes in microsurgery have started with multiday experimental courses on the rat model. These courses have offered a low threat supervised high fidelity laboratory setting in which students can steadily and rapidly progress. This simulated environment allows students to make and recognise mistakes in microsurgery techniques and thus shifts any related risks of the early training period from the operating room to the lab. To achieve a high level of skill acquisition before beginning clinical practice, students are trained on a comprehensive set of exercises the rat model can uniquely provide, with progressive complexity as competency improves. This paper presents the utility of the classical rat model in three of the earliest microsurgery training centres and the new prospects that this versatile and expansive training model offers.

Keywords Microsurgery / Models, educational / Rats / Laboratories
Correspondence:

Ali Mahmoud Ghanem

Academic Plastic Surgery Group, Centre for Cutaneous Research, Barts and the London School of Medicine and Dentistry, Blizard Institute, 4 New Ark Street, London E1 2AT, London, UK

Tel: +44-20-7882-7173

Fax: +44-20-7882-7171

E-mail:a.ghanem@qmul.ac.uk

No potential conflict of interest relevant to this article was reported.

\section{INTRODUCTION}

The increase in restrictions to animal use and the financial constraints of training in recent years have led to the development and spread of many non-living animal models for microsurgery simulation. Such models are numerous and include a huge spectrum such as rat cadavers, cryo-preseved rat aortas, chicken and turkey wings, leaves and grape skin, human cadaver vessels, and different styles of plastic simulation materials [1-4]. Most of these non-living models are sufficient in enabling students to acquire the basic set of microsurgery skills, especially in the early stages of training. At this beginner stage, the set of skills required includes a basic working knowledge of the surgical microscope, handling the microsurgery instruments and small sutures, and basic suturing and anastomosis techniques. Using non-living models for this purpose decreases the number of live animals used for training purposes, and gives students confidence when working with living tissues.

However, the live rat animal model remains an indispensable model for many training microsurgical courses around the world. The use of this model in microsurgery training stretches back to the early 1960's, when pioneers such as Lee [5] identi- 
fied the need for low cost surgical models that could meet the clinical needs of the day. He and subsequent researchers went on to develop organ transplant models in the rat to help address the current immunological issues at that time. It became evident that there was a need to transfer these skills to the clinical sector, as these new microsurgical techniques opened up new surgical possibilities. This, in return, led to the establishment of microsurgical training courses utilizing the rat model across both shores of the Atlantic and the expansion of training [6].

\section{THE DEVELOPMENT OF RAT-MOD- EL MICROSURGERY TRAINING COURSES: A TALE OF THREE CITIES}

Many different microsurgery training courses have been successful in training surgical specialists from different specialties and countries. Even though they differ in their set-ups and programs, the basic curriculum is very similar, and we will briefly describe three of the longest serving courses using rats as a classical training model for microsurgery training: Paris School of Surgery (Paris, France), Northwick Park workshops (London, UK), and Columbia University (New York, USA).

The Paris School of Surgery is the longest serving out of eighteen training courses on the record to date in France, all of which are either basic 'certificate' courses or advanced university 'diploma' courses. The training lab was established in 1976 by Dr. Alain Gilbert, Gisèle Amichot, and Josette Legagneux as instructors. There is an in-house course manual [7], and the pedagogical approach designed at the beginning of the programme is still followed today. Currently, the course is directed by Professor Alain Masquelet. The course accepts an average of 60 students a year for its basic certificate training, and 50 students can take the advanced course (university diploma). The course teaches about $60-70$ surgeons per year, and to date, the course has taught over 3,000 surgeons [8].

In the United Kingdom (working within Home Office guidelines for the use of animals), basic microsurgery workshops were established at Northwick Park Institute of Biomedical Research in 1979 by Professor Colin Green and Sandra Shurey, and over 3,000 surgeons have benefited from this training to date. A course manual was also written in-house to explain microsurgical theory and the use of the rat model, and to accompany the exercises incorporated into these workshops [9].

At Columbia University (CU), the Microsurgery Research and Training Lab was established in the early 1980 s by Dr. Harold M Dick in the Department of Orthopedic Surgery, and now it is under the leadership of Dr. Melvin P. Rosenwasser and Dr. Yelena Akelina, training over 150 surgeons every year, from 12 special- ties and more than 45 countries.

The three centres' basic courses are very similar, with slight variations, and here we note the common educational philosophy and style that is used. At the very beginning of the course, introductory videos and short lectures from the instructors are used to put students in the right mindset for learning and prepare them for the difficult and humbling experience of handling microsurgery for the first time. New techniques and exercises are introduced with a gradual increase in difficulty in parallel to the rise of students' confidence and frustration management.

All of the courses emphasise the importance of the right attitude and psychology set in achieving a successful outcome in microsurgery. All surgeons were first instructed on the use, care, and setup of the operating microscope, followed by basic interrupted suturing exercises on a rubber glove model to learn the difference between macro and micro-suturing. When this was mastered, the anaesthetised rat model was introduced.

In all courses, the rats are anesthetised intraperitoneally using a ketamine $(75-95 \mathrm{mg} / \mathrm{kg}$ ) and xylazine $(5-8 \mathrm{mg} / \mathrm{kg})$ cocktail and constantly monitored by the instructor and students for the depth of anesthesia. The rats' groin area is surgically prepared by standard methods and the femoral vessels are exposed, clamped, transected, and then anastomosed with 8 interrupted sutures using 10-0 nylon according to the standard methods of Acland [10].

Classical exercises were developed to take surgeons through a series of microsurgical maneuvers that would develop their skills in one week involving 35 to 40 hours of hands-on experience. All of the basic exercises utilised the femoral artery and vein, the epigastric artery and vein, and the sciatic nerve (Fig. 1). Surgeons would work at low- to mid-range magnification $(\times 4-\times 15)$.

The rat femoral area is used for basic exercises in preference to the aorta, carotid artery, or vena cava, as mistakes are easily managed and do not usually result in fatal hemorrhage. In the basic microsurgery skills course ( 3 days in Paris vs. 5 days in London and New York), surgeons learn how to prepare and care for the operative site, and how to prepare and care for micro-vessels ranging in size from 0.5 to $2 \mathrm{~mm}$. They also perform interrupted suturing with 10/0 stitches on both individual end-to-end and end-to-side anastomoses using rat models of vein grafting and free flaps.

During the same time, students also learn how to safely apply clamps, the action to be taken if a clamp slips, and how to place stitches with a view to correct tension, bite sizes, and stitch placement according to the type of vessel, including how to remove stitches safely when necessary, as well as correctly interpreting patency. 


\section{Fig. 1. Basic rat model exercises}

(A) The femoral artery and vein in the rat model. (B) Interpositional vein graft: femoral vein into femoral artery. (C) End-to-side anastomosis: femoral artery into femoral vein. (D) End-to-side arterial and venous anastomosis (groin flap). (E) Rat superficial inferior epigastric artery flap. (F) Rat sciatic nerve epineural repair.
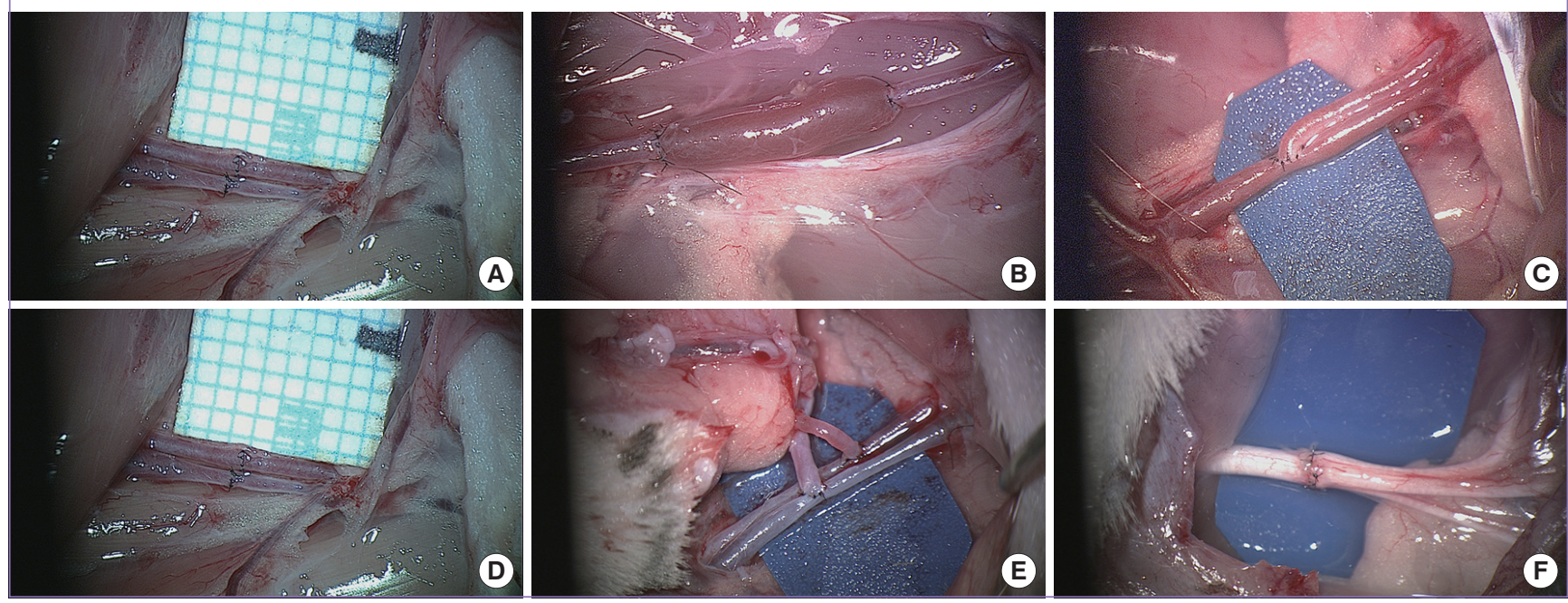

\section{RAT MODEL BASIC SKILLS COURSE COMPONENTS}

\section{Paris School of Surgery basic microsurgery course}

In the basic course, students undergo 3 days of training $(20$ hours in total). Eight hours of the course is dedicated to theoretical lessons and 12 hours to practical training. During the course, the students learn how to use the microscope as well as six basic techniques of microsurgery, namely end-to-end anastomosis on synthetic and rat femoral vessels as well as vein graft to arterial defects (Fig. 1A, B). The training, however, is not sufficient for achieving competency. It is simply an introduction to microsurgery and its challenging techniques. Table 1 highlights the training exercises taught in this basic course.

\section{London Northwick Park Institute for Medical Research (NPIMR) course}

The Northwick Park basic microsurgery workshop runs over the course of one week (5 training days), utilizing the rat as its main training model. The exercises taught in this basic course (Table 2 ) include end-to-end rat femoral artery (approximate average diameter of $1 \mathrm{~mm}$ ) and vein (approximate average diameter of 2 $\mathrm{mm}$ ) (Fig. 1A); rat femoral vein graft into the femoral artery (2$\mathrm{mm}$ vessel end-to-end into $1-\mathrm{mm}$ vessel), which also involves surgeons learning how to cope with discrepant-sized vessels (Fig. 1B); end-to-side rat femoral artery into the femoral vein (1-mm vessel into 2-mm vessel) (Fig. 1C); rat groin flap (Fig. 1D, E) and nerve repair using the rat sciatic nerve model (2-mm epineural repair) (Fig. 1F). Some students go on to perform epigastric vein graft into femoral artery (1-mm vessel into $1-\mathrm{mm}$ vessel, with a
Table 1. Paris School of Surgery basic microsurgery course

\begin{tabular}{|ll|}
\hline $\begin{array}{c}\text { Course } \\
\text { day }\end{array}$ & \multicolumn{1}{c|}{ Exercise taught } \\
\hline Day1 & $\begin{array}{l}\text { Introduction to the microsurgical workshop } \\
\text { Use and care of the operating microscope } \\
\\
\end{array}$ \\
& $\begin{array}{l}\text { Microsurgical suturing techniques on a latex glove } \\
\text { End-to-end anastomosis of a simulated vessel (Silicone tube) }\end{array}$ \\
Day 2 & $\begin{array}{l}\text { End-to-end anastomosis of the rat carotid artery } \\
\text { End-to-end anastomosis of the rat jugular vein } \\
\text { End-to-end anastomosis of the rat abdominal aorta }\end{array}$ \\
Day 3 & $\begin{array}{l}\text { End-to-end anastomosis of the rat femoral artery } \\
\text { End-to-end anastomosis of the rat femoral vein } \\
\text { Interpositional vein graft of the rat jugular vein into the abdominal aorta }\end{array}$ \\
\hline
\end{tabular}

difference in vessel wall thickness) or even raise a groin flap on the epigastric artery $(0.5 \mathrm{~mm})$ and vein $(1 \mathrm{~mm})$ (Fig. 2A).

\section{New York Columbia University basic microsurgery course}

At Columbia University (CU), the basic microsurgery training course is also taught over 5 working days ( 40 training hours). As in Paris and London, the CU basic skills course consists of exercises for teaching the students basic microsurgery techniques such as end-to-end interrupted suturing of vessels using the rat femoral artery and vein model (Fig. 1A); interpositional vein graft (Fig. 1B); end-to-side anastomosis of arteries and veins that gives the student the ability to perform both arteriotomy and venotomy (Fig. 1C); and peripheral epineural nerve repair (Fig. $1 F)$. However, there are a few extra points emphasised during the Columbia University course: 1) End-to-end arterial anastomosis $(1 \mathrm{~mm})$ is taught in both the conventional way as well 
Table 2. Paris School of Surgery advanced microsurgery (University Diploma) course

\begin{tabular}{|c|c|}
\hline Course session & Exercise taught \\
\hline Session 1 & Anaesthesia, analgesia and the rat model preparation \\
\hline Session 2 & End-to-end anastomosis of the rat femoral artery \\
\hline Session 3 & End-to-side anastomosis of the rat femoral artery to the femoral vein \\
\hline Session 4 & End-to-end anastomosis of the rat abdominal aorta \\
\hline Session 5 & End-to-end anastomosis of the rat carotid artery \\
\hline Session 6 & End-to-end anastomosis of the rat external jugular vein \\
\hline Session 7 & Interpositional vein graft of the external jugular vein into the carotid artery \\
\hline Session 8 & Abdominal aorta bypass graft using the external jugular vein \\
\hline Session 9 & Carotid artery collateral graft using the external jugular vein \\
\hline Session 10 & Carotid artery bypass graft using a loop of the external jugular vein \\
\hline Session 11 & End-to-side anastomosis of the carotid artery to the external jugular vein \\
\hline Session 12 & End-to-side anastomosis of the rat aorta to the right iliac artery \\
\hline Session 13 & End-to-side anastomosis of the rat portal vein to the inferior vena cava \\
\hline Session 14 & Ureter end-to-end anastomosis \\
\hline Session 15 & Right kidney autotransplantation with end-to-end anastomosis of the renal artery and vein \\
\hline Session 16 & Right kidney autotransplantation with end-to-side anastomosis of the renal artery to the aorta and the renal vein to the inferior vena cava \\
\hline Session 17 & Kidney transplantation (from left to right) \\
\hline Session 18 & Lymphaticovenous anastomosis of the rat thoracic duct into the external jugular vein \\
\hline Session 19 & End-to-end anastomosis of the rat tail artery \\
\hline Session 20 & Epigastric vein graft into the femoral artery \\
\hline Session 21 & Femoral artery bypass graft using the epigastric vein \\
\hline Session 22 & End-to-end anastomosis of the rat epigastric artery and vein \\
\hline Session 23 & Rat groin flap based on the end-to-end anastomoses of the epigastric artery and vein \\
\hline Session 24 & Rat groin flap based on the end-to-side anastomoses of the femoral artery and vein \\
\hline Session 25 & Groin flap based on the femoral vessels transposed to the carotid artery and jugular vein in the neck \\
\hline Session 26 & Groin flap based on the femoral vessels transposed to the brachial vessels in the axilla \\
\hline Session 27 & Epineural repair of the rat sciatic nerve \\
\hline Session 28 & Rat limb transplantation \\
\hline Session 29 & Rat fallopian tube end-to-end anastomosis and auto-graft repair \\
\hline Session 30 & Rat cardiac transplantation \\
\hline
\end{tabular}

as by one-way-up or the posterior-wall-first technique. 2) The course advocates the use of the inguinal fat pad as a hemostasis tool at the end of each exercise to reduce the bleeding time and to demonstrate the effect of fat tissue in hemostasis [11].3) The course stresses the need for the students to learn how to control anastomosis bleeding caused by gapping or uneven spacing without reapplying the approximating clamps in order to reduce the risk of thrombosis.

Table 3 highlights the training exercises taught in this basic course.

\section{RAT MODEL ADVANCED SKILLS COURSE COMPONENTS}

Experienced surgeons who want to further develop their skills are encouraged to take the advanced courses available at all three centres, which also make use of the rat model.

\section{Paris School of Surgery advanced microsurgery course}

In this university diploma level advanced course, students are exposed to about twenty different training exercises on the rat. These include end-to-end anastomosis on vessels up to $1 \mathrm{~mm}$ in diameter (Fig. 2A), grafts (Fig. 1B), bypass (Fig. 2B), kidney transplantation (Fig. 2D), and a bundle of flap transfers (Fig. 1E). The course comprises 30 training sessions that run weekly over an 8 month period. In total, 120 hours of training is required to complete the training curriculum. The teaching method is based on stepwise increases in the difficulty of exercises. During the first 15 sessions, students do not repeat the same exercise. Rather, they practice a different more difficult technique every time. At the completion of the course, a final exam is applied, and a previous study showed that the success rate is related to the number of training hours [8]. Table 4 summarizes the training exercises taught in the Paris advanced course.

\section{London Northwick Park Institute advanced course}

This advanced microsurgical skills course is taught over a period of five days ( 40 hours). The exercises vary and are tailored to the students' ability and learning needs. As summarised in Table 5, the exercises taught routinely include micro-dissection skills in 


\section{Fig. 2. Advanced rat model exercises}

(A) Rat epigastric artery and vein (diameter less than $1 \mathrm{~mm}$ ). (B) Rat carotid artery loop (the femoral used as a graft-bypass). (C) A plastic dome simulator for anastomosis in a deep restrictive field. (D) The rat kidney autotransplantation exercise.
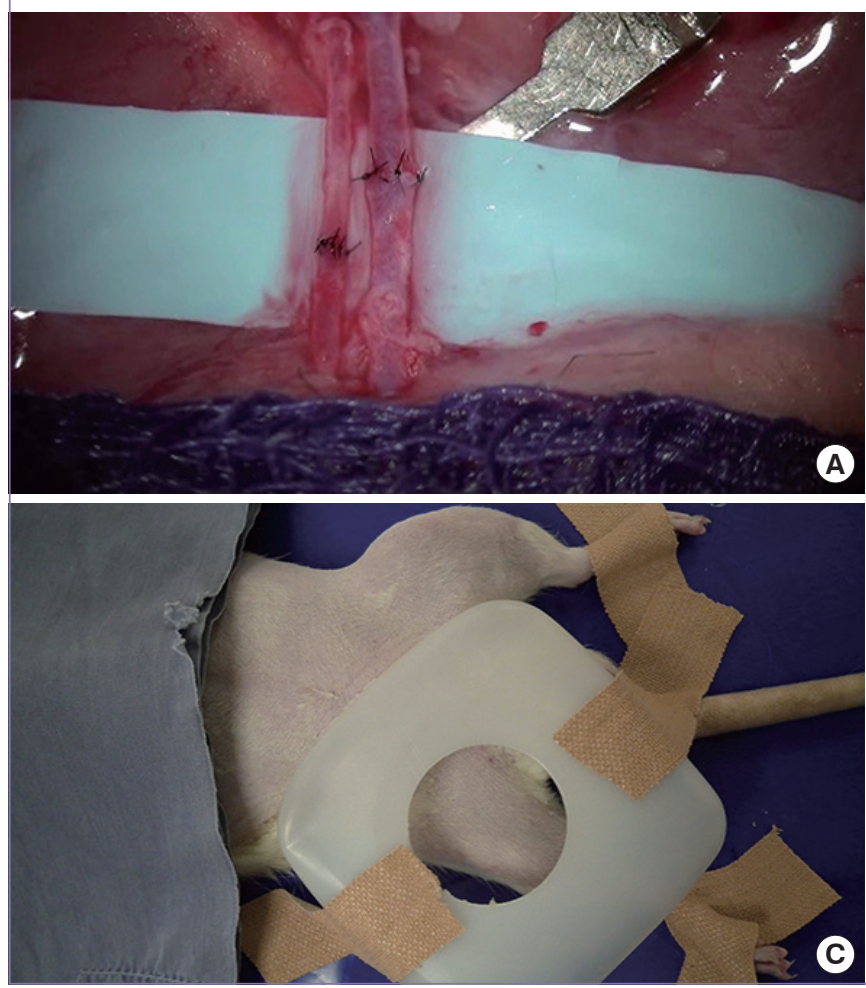

vessels below $1 \mathrm{~mm}$ (Fig. 2A); free tissue transfer using end-toend and end-to-side anastomosis techniques (Figs. 1D, E, 2A); vascular grafts and bypasses (Figs. 1B, 2B); microvascular anastomosis in a deep restrictive area (Fig. 2C); vessel anastomosis without the use of double clamps; operation under maximum magnification (up to $\times 25$ ); and continuous suturing. Additional specialised techniques taught to the candidates of specific specialties such as vasovasostomy, epididymovasostomy, and organ transplantation can also be incorporated.

\section{New York Columbia University advanced microsurgery course}

At this institution, an advanced course for one week (40 hours) can be organized upon request. This course also utilises the rat model, and as in the London and Paris advanced courses, the rat model exercises are expanded and modified to teach students a bundle of advanced microsurgical techniques (Table 6). Endto-end anastomosis on a rat carotid artery, for example, gives the students the ability to work at different angles for suturing and various dissection skills. Interpositional vein grafts are taught with the rat epigastric vein $(1 \mathrm{~mm})$ inside the femoral artery (1 $\mathrm{mm}$ ) to teach the handling of small vessels (supermicrosurgery). Furthermore, different free flaps, such as the rat groin flap, serratus anterior muscle flap, latissimus dorsi muscle flap, and myo-
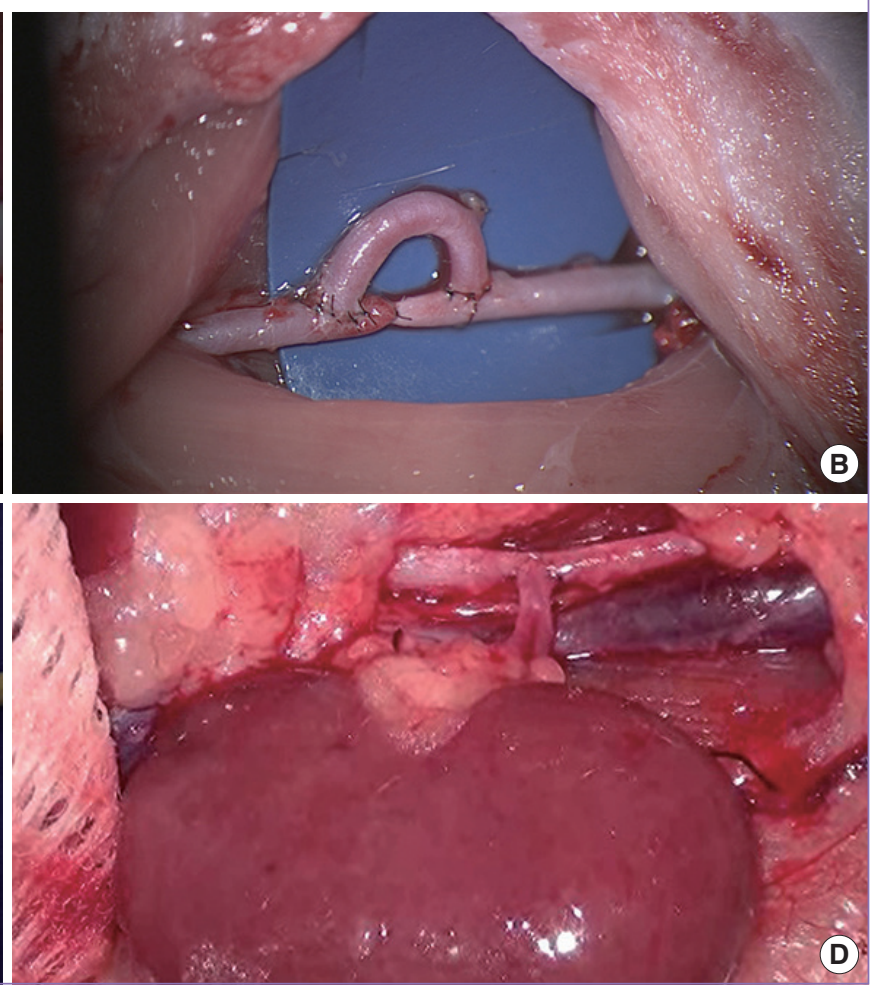

Table 3. Northwick Park (London) basic course

\begin{tabular}{|c|c|}
\hline $\begin{array}{c}\text { Course } \\
\text { day }\end{array}$ & Exercise taught \\
\hline Day 1 & $\begin{array}{l}\text { Introduction to the microsurgical workshop } \\
\text { Use and care of the operating microscope } \\
\text { Microsurgical suturing techniques on a latex glove } \\
\text { End-to-end anastomosis of a simulated vessel } \\
\text { (Penrose drain) } \\
\text { End-to-end anastomosis of the femoral artery }\end{array}$ \\
\hline Day 2 & $\begin{array}{l}\text { End-to-end anastomosis of the femoral artery } \\
\text { End-to-end anastomosis of the femoral vein } \\
\text { End-to-end anastomosis of the femoral artery and vein }\end{array}$ \\
\hline Day 3 & $\begin{array}{l}\text { End-to-side anastomosis of the femoral artery to the } \\
\text { femoral vein } \\
\text { Femoral vein graft into the femoral artery }\end{array}$ \\
\hline Day 4 & $\begin{array}{l}\text { Epigastric vein graft into the femoral artery } \\
\text { Femoral or epigastric vein graft into the femoral artery } \\
\text { Epineural repair of the sciatic nerve }\end{array}$ \\
\hline Day 5 & $\begin{array}{l}\text { Groin flap based on the end-to-end anastomoses of the } \\
\text { epigastric artery and vein } \\
\text { Repeat the first exercise of the week:- End-to-end } \\
\text { anastomoses of the femoral artery and vein } \\
\text { Free choice of any of the week's exercises }\end{array}$ \\
\hline
\end{tabular}

cutaneous flaps could be incorporated to teach the principles of free tissue transfer. Additional specialised exercises such as vasovasostomy and Fallopian tubal repair could also be included 
Table 4. Northwick Park (London) advanced course

\begin{tabular}{|cl|}
\hline $\begin{array}{c}\text { Course } \\
\text { day }\end{array}$ & \multicolumn{1}{c|}{ Exercise taught } \\
\hline Day 1 & $\begin{array}{l}\text { Introduction to the microsurgical workshop } \\
\text { End-to-end anastomosis of the femoral artery } \\
\text { End-to-end anastomosis of the femoral vein } \\
\text { End-to-end anastomosis of the femoral artery without double clamp } \\
\text { End-to-end anastomosis of the femoral vein without double clamp }\end{array}$ \\
Day 2 & $\begin{array}{l}\text { End-to-side anastomosis of the femoral artery to the femoral vein } \\
\text { Femoral vein graft into the femoral artery }\end{array}$ \\
& $\begin{array}{l}\text { Epigastric vein graft into the femoral artery } \\
\text { Day } 3\end{array}$ \\
& $\begin{array}{l}\text { Cavity work: End-to-end anastomosis of the femoral artery } \\
\text { Femoral artery loop to carotid artery } \\
\text { Vaso-vasostomy } \\
\text { Epineural repair of the sciatic nerve } \\
\text { Groin flap based on the end-to-end anastomoses of the epigastric } \\
\text { artery and vein } \\
\text { Kidney transplantation with end-to-end anastomosis by continuous } \\
\text { suturing }\end{array}$ \\
Day 5 & $\begin{array}{l}\text { Groin flap based on the end-to-side anastomoses of the epigastric } \\
\text { artery and vein } \\
\text { Kidney transplantation with end-to-side anastomosis by continuous } \\
\text { suturing }\end{array}$ \\
\hline
\end{tabular}

Table 5. Columbia University (New York) basic course

\begin{tabular}{|cc|}
\hline $\begin{array}{c}\text { Course } \\
\text { day }\end{array}$ & \multicolumn{1}{c|}{ Exercise taught } \\
\hline Day 1 & $\begin{array}{l}\text { Introduction to mental preparation in microsurgery, use of the operating } \\
\text { microscope, mechanics of microsurgical suturing } \\
\text { Microsurgical suturing techniques on a latex glove } \\
\text { End-to-end anastomosis of a simulated vessel (silastic tube) } \\
\text { End-to-end anastomosis of the femoral artery }\end{array}$ \\
Day 2 & $\begin{array}{l}\text { End-to-end anastomosis of the rat femoral artery using the one-way-up } \\
\text { technique } \\
\text { End-to-end anastomosis of the rat femoral vein with interrupted suturing }\end{array}$ \\
Day 3 & $\begin{array}{l}\text { Interpositional vein graft using the femoral vein into a femoral artery } \\
\text { defect }\end{array}$ \\
& $\begin{array}{c}\text { End-to-end arterial and venous anastomosis without approximator } \\
\text { clamps }\end{array}$ \\
Day 4 & $\begin{array}{l}\text { End-to-side anastomosis using the femoral artery to the femoral vein } \\
\text { End-to-side anastomosis using the femoral vein to the femoral artery }\end{array}$ \\
Day 5 & $\begin{array}{l}\text { Epineural repair of the rat sciatic nerve } \\
\text { Exam: end-to-end arterial and venous anastomosis within a time limit }\end{array}$ \\
\hline &
\end{tabular}

according to the student's specialty and specific goals associated with her/his surgical practice.

The following is a summary of the advanced exercises common to the three centres that they have developed to cover the skills training needs of the advanced trainees. These exercises can be an excellent foundation for higher skills necessary for clinical scenarios such as organ transplantation and complex chimeric flap reconstruction.

\section{Renal transplantation}

Renal transplantation in the rat incorporates meticulous dis-
Table 6. Columbia University (New York) advanced course

\begin{tabular}{|c|c|}
\hline $\begin{array}{c}\text { Course } \\
\text { day }\end{array}$ & Exercise taught \\
\hline \multirow[t]{4}{*}{ Day 1} & End-to-end arterial anastomosis using interrupted suturing \\
\hline & End-to-end venous anastomosis using interrupted suturing \\
\hline & End-to-side anastomosis using femoral artery to the femoral vein \\
\hline & End-to-side anastomosis using femoral vein to the femoral artery \\
\hline \multirow[t]{3}{*}{ Day 2} & End-to-end rat carotid artery anastomosis \\
\hline & $\begin{array}{l}\text { Collateral end-to-side bypass of the carotid arteries using a femoral } \\
\text { artery graft }\end{array}$ \\
\hline & $\begin{array}{l}\text { Interpositional vein graft using the rat epigastric vein into the femoral } \\
\text { artery }\end{array}$ \\
\hline Day 3 & Rat groin free flap based on the femoral vessels as a pedicle \\
\hline Day 4 & $\begin{array}{l}\text { Rat groin flap using the superficial inferior epigastric artery and vein } \\
\text { with 11-0 nylon }\end{array}$ \\
\hline \multirow[t]{5}{*}{ Day 5} & (Specialty and student educational needs dependent) \\
\hline & Vasovasostomy and Vasoepididymostomy \\
\hline & Fallopian tube repairs \\
\hline & Serratus anterior muscle flap to femoral vessels \\
\hline & Organ (renal) transplant with continuous suturing \\
\hline
\end{tabular}

section techniques, as it involves entwined vessels, different size disparities, vessel bifurcations, and differing orientations (vessel sizes $0.5-1 \mathrm{~mm}$ ). This was first put forward as a microsurgical training model (using a slightly different model) by Korber and Kraemer [12] in 1988.

The transplant is performed end-to-end on the opposite renal vessels or end-to-side onto the infra-renal aorta and vena cava, which requires careful dissection skills, as the vena cava and aorta are in close proximity (Fig. 2D). Continuous stitching with 10/0 suture is performed, utilizing the front-wall-first or back-wall-first method (this simulates working in constricted areas where it is difficult to access the back wall). Continuous stitching was first recommended by Man and Acland [13] in 1981. It is faster, but the budding micro-surgeon must be aware of tension (particularly in veins), friability, bite size, and the possibility of catching the back/front wall.

\section{The rat carotid loop}

This exercise requires careful dissection skills and meticulous suturing. The carotid artery is entwined closely within a sheath containing small veins and the vagus nerve. The femoral artery is removed and anastomosed with 10/0 interrupted sutures in an end-to-side loop into the carotid (Fig. 2B).

Anastomotic techniques in a deep field (Fig. 2C) without the double clamp and at $\times 25$ magnification (Fig. 2A)

Anastomosing in deep restricted areas is mimicked by the use of a plastic jig that fits over the rat femoral area. This gives an opening field $3 \mathrm{~cm}$ wide and $3 \mathrm{~cm}$ deep. A rat femoral artery and vein are then anastomosed end-to-end through this aperture. 
Some clinical centres do not use or have access to double clamps, so the anastomotic techniques taught do not utilise this, and the rat femoral artery and vein anastomosis can be completed by starting at the centre of the back wall first or using a 1,200 or 1,800 orientation.

For very small vessels of $1 \mathrm{~mm}$ and below, a higher magnification is needed. Trainees learn that at this level of magnification, the light is not so bright and the depth of field is much shorter, meaning that the anastomosis must be carried out in a horizontal plane.

Rat groin flap models involve end-to-end anastomosis of the epigastric artery and vein (Fig. 1A). This exercise can be performed utilising an end-to-side anastomosis of these vessels onto the femoral artery and vein. The epigastric vein can also be anastomosed as a graft into the epigastric artery.

\section{Vasovasostomy and epididymovasostomy}

Rat models of vasovasostomy and epididymovasostomy are good substitutes for clinical operations due to their relatively large size in the rat, and are used routinely in vasectomy reversal workshops for urologists in the UK [7].

\section{NEW HORIZONS IN MICROSUR- GERY TRAINING}

Fifty years after Sun Lee's manual describing microsurgery techniques in the rat to address the needs of reconstructive surgeons of that time, the clinical world is again in need of further microsurgical training interventions with the advent of new horizons in microsurgery, namely, the advent of perforator flaps and lymphatic anastomosis. These new emerging techniques utilise vessels of below $1 \mathrm{~mm}$. This has been termed 'supra-microsurgery' [14]. In addition, the use of microsurgical techniques is now being incorporated into many new areas of the clinical specialties. In 1979, most new micro-surgeons were from the field of plastic surgery. In contrast, current students come from a variety of specialties and include maxillo-facial, oral/otolaryngology (ENT), orthopaedic, hand, general, urology, obstetrics, paediatric, cardiac, and transplant surgeons.

When surgeons gain experience in microsurgery, the horizons for utilising the rat model are virtually endless, given the possibility to learn how to perform tail, toe, and organ transplants, to work with vessels with a size discrepancy, to work with video-assisted devices, to suture with continuous stitching, and other difficult exercises [15-25]. New techniques with the robot-assisted microsurgery open a new door to utilise the classic rat model for teaching surgeons from different specialties to perform microsurgical procedures using robotic arms. Other techniques and procedures that can be utilised in the rat for microsurgical training (but are yet to be permitted in the UK by current Home Office rules) include most of the organ transplants described by Lee [5] such as those of the liver, lung, small and large bowel, stomach, and pancreatico-duodenum. Additional exercises can include other free flaps, and muscle, bone, and limb transplantations.

\section{CONCLUSIONS}

It has been established that microsurgery training courses using rat models offer many advantages. They greatly enhance students' surgical skills and provide the highest fidelity simulator for clinical microsurgery. The use of rat models in advanced courses under a supervised training programme provides an excellent simulation model for complex microsurgical reconstruction procedures. As such, the rat model remains the best preparation for achieving high standards of competency in microsurgery. Advances in microsurgical reconstruction demand new educational interventions. The live rat is one of the most versatile models in microsurgery training courses worldwide, and 50 years after microsurgery was first pioneered, the rat model is still irreplaceable for advanced microsurgery skill acquisition. Its prospects include future educational roles in perforator flap techniques and robotassisted microsurgery.

\section{REFERENCES}

1. Austin GT, Hammond FW, Schaberg SJ, et al. A laboratory model for vascular microsurgery. J Oral Maxillofac Surg 1983; 41:450-5.

2. Kaufman T, Hurwitz DJ, Ballantyne DL. The foliage leaf in microvascular surgery. Microsurgery 1984;5:57-8.

3. Weber D, Moser N, Rosslein R. A synthetic model for microsurgical training: a surgical contribution to reduce the number of animal experiments. Eur J Pediatr Surg 1997;7: 204-6.

4. Lannon DA, Atkins JA, Butler PE. Non-vital, prosthetic, and virtual reality models of microsurgical training. Microsurgery $2001 ; 21: 389-93$.

5. Lee S. Historical events on development of experimental microsurgical organ transplantation. Yonsei Med J 2004;45: 1115-20.

6. Green CJ. Microsurgery in the clinic and laboratory. Lab Anim 1987;21:1-10.

7. Gilbert A, Legagneux J, Lapierre F. Apprentissage de la microchirurgie. In: Techniques chirurgicales: chirurgie plastique reconstructrice et esthetique (45-025). Paris: Encycl Med Chir; 1998. p.24.

8. Cabrol C, Gilbert A. Training of microsurgery in the labora- 
tory of the Hopitaux de Paris. Chirurgie 1991;117:145-8.

9. Green C, Simpkin S; Clinical Research Centre (Harrow, London, England). Basic microsurgical techniques: a laboratory manual. Harrow, Middlesex, UK: Surgical Research Group, MRC Clinical Research Centre; 1986.

10. Acland RD. Practice manual for microvascular surgery. St. Louis: Mosby; 1980.

11. Akelina Y, Danilo P. Endogenous adipose tissue as a hemostatic: use in microsurgery. Microsurgery 2008;28:192-6.

12. Korber KE, Kraemer BA. Heterotopic renal transplantation in the rat: an advanced microsurgical training exercise. Microsurgery 1988;9:286-91.

13. Man D, Acland RD. Continuous-suture technique in microvascular end-to-end anastomosis. J Microsurg 1981;2:23843.

14. Koshima I, Inagawa K, Urushibara K, et al. Supermicrosurgical lymphaticovenular anastomosis for the treatment of lymphedema in the upper extremities. J Reconstr Microsurg 2000;16:437-42.

15. Bao JY. Rat tail: a useful model for microvascular training. Microsurgery 1995;16:122-5.

16. Crosby NL, Clapson JB, Buncke HJ, et al. Advanced nonanimal microsurgical exercises. Microsurgery 1995;16:655-8.

17. Zhang F, Chin BT, Ho PR, et al. Rat tail replantation as a training model for microvascular procedures of digit replantation. Microsurgery 1998;18:364-7.
18. Akan M, Cakir B, Akoz T. "Open y” technique in vessel diameter discrepancy. Microsurgery 2006;26:506-14.

19. Blidisel A, Jiga L, Nistor A, et al. Video-assisted versus conventional microsurgical training: a comparative study in the rat model. Microsurgery 2007;27:446-50.

20. Galvao FH, Bacchella T, Cerqueira Machado M. Teaching intestinal transplantation in the rat for medical student. Microsurgery 2007;27:277-81.

21. Miyamoto S, Okazaki M, Ohura N, et al. Comparative study of different combinations of microvascular anastomoses in a rat model: end-to-end, end-to-side, and flow-through anastomosis. Plast Reconstr Surg 2008;122:449-55.

22. Mofikoya BO, Ugburo AO, Bankole OB. Microvascular Anastomosis of Vessels Less Than $0.5 \mathrm{~mm}$ in Diameter: A Supermicrosurgery Training Model in Lagos, Nigeria. J Hand Microsurg 2011;3:15-7.

23. Sakrak T, Kose AA, Karabagli Y, et al. Rat tail revascularization model for advanced microsurgery training and research. J Reconstr Microsurg 2011;27:391-6.

24. Spetzger U, von Schilling A, Brombach T, et al. Training models for vascular microneurosurgery. Acta Neurochir Suppl 2011;112:115-9.

25. Yazici I, Cavusoglu T, Karakaya EI, et al. Microsurgical training model for lymphaticovenous anastomosis in rat. Microsurgery 2012;32:420-2. 